\title{
Detection and quantification of probiotic bacteria using optimized DNA extraction, traditional and real-time PCR methods in complex microbial communities
}

\author{
Abdulamir A. S. ${ }^{1,2}$, Yoke T. S. ${ }^{3}$, Nordin N. ${ }^{3}$ and Abu Bakar F. ${ }^{1,3 *}$ \\ ${ }^{1}$ Institute of Bioscience, University Putra Malaysia, 43400 Serdang, Selangor, Malaysia. \\ ${ }^{2}$ Microbiology department, College of Medicine, Al-nahrain University, 14222, Baghdad, Iraq. \\ ${ }^{3}$ Faculty of Food Science and Technology, University Putra Malaysia, 43400 Serdang, Selangor, Malaysia.
}

Accepted 26 November, 2009

\begin{abstract}
The aim of this study is to optimize molecular detection and quantification methods of probiotic bacteria in complex microbial communities that have long been difficult for traditional culture-based methods. Traditional and real-time PCR were optimized to detect and quantify Lactobacillus spp. and Bifidobacterium spp. in complex microbial community. Fish and shrimp sauce were used as a model for complex microbial community. Directly form samples, 4 DNA extraction methods, primers specificity, PCR, and real-time PCR procedures were optimized, tested in comparison with samples, enriched bacteria and related standard bacterial strains, E. coli, Bacteroides, Enterococcus and Salmonella. Results showed that extracted genomic DNA using Wizard ${ }^{\circledR}$ Genomic DNA Purification Kit showed the highest yield, quality and performance. Moreover, the specificity of the primer set specific for Lactobacillus spp. and Bifidobacterium spp. was checked and found highly specific. The sensitivity of real-time PCR was higher than the conventional PCR and its quantifying potential is very precise for the detection and quantification of Lactobacillus spp. but not Bifidobacterium spp. which was absent in the tested samples. In conclusion, PCR and real-time PCR assays could be used very efficiently in quantifying and detecting Lactobacillus spp. that are present in very PCR-suppressive and complex microbial environment.
\end{abstract}

Key words: PCR, real-time PCR, DNA extraction, Bifidobacterium spp., Lactobacillus spp., fermentation, probiotic.

\section{INTRODUCTION}

Probiotic bacteria are essential for healthy gastrointestinal function. The action of probiotics on intestinal flora results in vital benefits, including protection against pathogens, development of the immune system (Isolauri et al., 2002) and positive effects on colonic health and host nutrition (Umesaki and Setoyama, 2000). The use of Bifidobacterium as probiotics in food or pharmaceutical products is of high value. The most representative application of Bifidobacteria in diet is Bifidobacteria yogurt and Bifidobacteria milk, used as non-fermented milk (Ishibashi et al., 1997). Alike, Lactobacilli bacteria

*Corresponding author. E-mail: fatimah_upm_fst@yahoo.com. Tel: 00-60-389468375. Fax: 00-60-89423552. are extensively used as probiotics and used technologically as food-associated micro-organism as they are generally recognized as safe (GRAS) (Salminen et al., 1998).

Probiotic bacteria are found in some diet abundantly rendering such diet as a health supply for proper function of the intestine. Several indigenous microorganisms are found in fermented fish products including Bifidobacteria and Lactobacilli (Salinas et al., 2008). The use of fermentation as a preservation method for fish has been of great value from earliest times. Among these products, fish sauce and shrimp sauce are the most popular products which are being used as a condiment in Southeast Asia (Yung et al., 2006). As fish fermentation involves minimal bacterial conversion of carbohydrates to lactic acid but entails extensive tissue degradation by 
proteolytic and lipolytic enzymes, fish and shrimp sauce have been shown to be the best specimens for the highly complex microbial communities (Muhling et al., 2008). Although fish and shrimp sauce harbor significant amounts of probiotic bacteria, the detection, isolation and enumeration of Bifidobacteria and Lactobacilli bacteria has always not been successful (Yongsawatdigul et al., 2007). This was attributed to the fact that fish and shrimp sauce are extremely complex microbial specimens in which most traditional culture methods of bacteria proved to be non-specific, non-accurate and due to the complexity of microbial mixture, too lengthy (Jaspers and Overmann, 1997). Unfortunately, after PCR advent, most detection and isolation of probiotic bacteria turned unsuccessful due to the lack of proper design and optimization of the molecular protocols to fit with such highly complex microbial specimens namely, fish and shrimp sauce (Muhling et al., 2008). PCR assays were not successfully applied on fermented products due to the presence of potent and complex diverse PCR inhibitors such as fermented fish products and due to difficult extraction of intact DNA (Podar et al., 2007).

Prior to the advent of PCR, identification of microorganisms relied on bacteriological methods and subsequent biochemical tests (Fairchild et al., 2006). Moreover, some of the biochemical tests such as gram-staining, oxidase and catalase tests for identification of bacteria were also not precise or perfect. On the other hand, anti16S rRNA conventional and real-time PCR proved to be superior in the detection and enumeration of many microorganisms. Nevertheless, their use has been limited to simple and uncomplicated specimens (Ray and Bhunia, 2008). Upon the rapid evolution of PCR assay, the realtime PCR provided an accurate, unambiguous identification and quantification of nucleic acid sequence (Klein, 2002) compared to conventional PCR. The real-time PCR allowed simultaneous amplification and quantification of specific nucleic acid sequences cycle-by-cycle which provided the platform for easy, rapid and accurate method of bacterial detection and enumeration (Logan and Edwards, 2004).

There is evident shortage of suitable and precise detection methods of Lactobacillus spp. and Bifidobacterium spp in complex microbial communities. Therefore, the purpose of this study was to optimize DNA extraction methods, test the most specific PCR primers and adjust the best molecular methods for precisely enumerating Lactobacillus spp. and Bifidobacterium spp. bacteria using real-time PCR. Two different genusspecific primer sets were being used in this study, ( $\mathrm{g}$ Bifid-F / g-Bifid-R) for Bifidobacterium and (Lacto-16S-F / Lacto-16S-R) for Lactobacillus. These primers were used to detect and quantify the 16S rRNA gene. PCR quantification offers the advantage that no prior knowledge of bacterial content is required when using genus-specific primers, since no correction for multiple gene copies has to be performed. For securing stringent conditions of the current study's objectives, a very complicated microbial community was chosen as a model in this study, namely fermented fish sauce and shrimp sauce.

\section{MATERIALS AND METHODS}

\section{Samples and media}

Three commercial samples of fish sauce, fish sauce A (Malaysia), fish sauce $B$ (Thailand) and fish sauce $C$ (China) and three samples of shrimp sauce D (Malacca, Malaysia), shrimp sauce E (Cheras, Malaysia) and shrimp sauce $F$ (Muar, Malaysia) were obtained from local market. Growth media used in this study were MRS Broth (Difco, USA), TPY Broth (Scharlau, European Union), Nutrient Agar (Oxoid LTD, England), MRS Agar (Difco, USA) and Ringer Solution (Merck kGaA, Germany). They were prepared according to manufacturers' instructions. All used media and instruments were autoclaved for $15 \mathrm{~min}$ at $121^{\circ} \mathrm{C}$ before being used.

\section{Preparation of samples and inocula}

A $10 \mathrm{~g}$ sample was taken aseptically from sample bottles and homogenized in $90 \mathrm{ml}$ of sterilized Ringer solution (Merck, Germany) to be prepared for DNA extraction (Podar et al., 2007; Yi-Ting et al., 2007). In parallel, for detecting target bacteria indirectly through an enrichment step for comparison with DNA extracted directly from samples, $1 \mathrm{ml}$ of the homogenized mixture was inoculated into $9 \mathrm{ml}$ of MRS Broth (Oxoid, UK) for Lactobacillus spp. and TPY Broth (Oxoid, UK) for Bifidobacterium spp. before incubated anaerobically for $72 \mathrm{~h}$ at $37^{\circ} \mathrm{C}$ in an anaerobic jar, which contained Anaerocult $\AA$ A (Merck, Germany). A $0.1 \mathrm{ml}$ of the inoculum from TPY and MRS broths was spread onto the surface of TPY and MRS Agar (Oxoid, UK) before incubated for $72 \mathrm{~h}$ at $37^{\circ} \mathrm{C}$ in anaerobic condition. The colonies observed on both agar surfaces were picked and streaked onto nutrient agar slope in triplicate. All the agar slopes were incubated again for $72 \mathrm{~h}$ at $37^{\circ} \mathrm{C}$, with bottle cap loosened under anaerobic condition before kept in refrigerator $\left(0-5^{\circ} \mathrm{C}\right)$ as stock culture.

\section{DNA extraction from samples}

Processed product samples, 1:10 diluted in Ringer solution, were centrifuged at $13,000 \mathrm{rpm}$ for $10 \mathrm{~min}$ after which the supernatant was removed and the remaining pellet was subjected to DNA extraction (Podar et al., 2007; Yi-Ting et al., 2007) using four different extraction protocols which were evaluated in this study. 


\section{DNA extraction via phenol-chloroform method}

Briefly, the pellet was dissolved with $467 \mu \mathrm{l}$ TE buffer (Sigma, USA), added with $30 \mu \mathrm{l}$ of $10 \%$ SDS (IBD, UK) and $3 \mu \mathrm{l} 20 \mathrm{mgml}^{-1}$ proteinase $\mathrm{K}$ (Sigma, USA). After incubation for $1 \mathrm{~h}$ at $37^{\circ} \mathrm{C}, 50 \mu \mathrm{l}$ phenol: chloroform: isoamyl alcohol (Merck, Germany) was added and mixed by gentle inversion. Aqueous phase was transferred to another new tube and added with $0.1 \mathrm{ml}$ of $3 \mathrm{M}$ sodium acetate (Sigma, USA), $0.6 \mathrm{ml}$ of isopropanol (Merck, Germany) and mixed slowly until DNA precipitated and DNA was spooled with pasteur pipette. DNA was dried and washed by dipping the end of the pipette into $1 \mathrm{ml}$ $70 \%$ ethanol (Merck, Germany) for 30 s before dissolving in $150 \mu \mathrm{l} \mathrm{TE} \mathrm{buffer} \mathrm{(Kochl} \mathrm{et} \mathrm{al.,} \mathrm{2005).}$

\section{DNA extraction via modified heat shock/boiled-cell method}

Briefly, $1 \mathrm{ml}$ sterile distilled water was added to the pellet, vortexed and subjected to heating temperature of $100^{\circ} \mathrm{C}$ for $20 \mathrm{~min}$. The suspension was then cooled immediately to $-20^{\circ} \mathrm{C}$ for $20 \mathrm{~min}$ and centrifuged at $13,000 \mathrm{rpm}$ for 3 min before the supernatant was kept in freezer $\left(0-5^{\circ} \mathrm{C}\right)$ (Keegan et al., 2005).

\section{DNA extraction via Kimchi modified method}

Briefly, the pellet was mixed with universal DNA extraction buffer (Promerga, USA) and $2 \mu$ proteinase $\mathrm{K}$ $\left(20 \mathrm{mgml}^{-1}\right.$ ) before shaking for $30 \mathrm{~min}$ at $37^{\circ} \mathrm{C}$. A $300 \mu \mathrm{l}$ of $20 \%$ SDS (IBD, UK) was added and mixture was incubated for $2 \mathrm{~h}$ at $65^{\circ} \mathrm{C}$ before centrifuged at 13,000 rpm for 3 min and the supernatant was mixed with equal amount 24:1 of chloroformamyl alcohol (Merck, Germany). The aqueous part was transferred to a new tube, and isopropanol and 70\% ethanol (Merck, Germany) were added to wash the pellet obtained before $100 \mu \mathrm{TE}$ buffer (Sigma, USA) was added to dissolve DNA (Podar et al., 2007).

\section{DNA extraction via the Wizard $^{\circledR}$ Genomic DNA Purification Kit}

The total genomic DNAs from samples were extracted using Wizard ${ }^{\circledR}$ Genomic DNA Purification Kit (Promega, USA), according to the manufacturer's instruction with some modifications. $10 \mathrm{ml}$ of the $1: 10$ diluted sample pellet were centrifuged at $13,000 \mathrm{~g}$ for $3 \mathrm{~min}$, washed and re-suspended in $700 \mu \mathrm{l}$ of glucose-Tris-EDTA buffer (50 $\mathrm{mM}$ glucose, $25 \mathrm{mM}$ tris- $\mathrm{HCl}$ from Sigma, USA and 10 mM EDTA from Merck, Germany, at pH 8.0). Lysozyme (Sigma, USA) was added to final concentration of 20 $\mathrm{mgml}^{-1}$ and incubated in water bath (Reciprocal Water
Bath Incubator Model, Certomat ${ }^{\circledR}$ WR) for $1 \mathrm{hr}$ at $37^{\circ} \mathrm{C}$ before the suspension was centrifuged at $13,000 \mathrm{~g}$ for 3 $\min$. Then, $600 \mu \mathrm{l}$ of nuclei lysis solution were added to the pellet to lyse the cell membrane before incubating for $5 \mathrm{~min}$ at $80^{\circ} \mathrm{C}$. After cooling at the room temperature, $3 \mu \mathrm{l}$ of RNase solution (Promega, USA) were added and the tubes were inverted for 5 times before the mixture was incubated again for $1 \mathrm{~h}$ at $37^{\circ} \mathrm{C}$.

$200 \mu \mathrm{l}$ of protein precipitation solution (Promega, USA) were added into the mixture to purify the genomic DNA and the reaction mixture was vigorously vortexed for $20 \mathrm{~s}$. Afterwards, the mixture was incubated in ice for $5 \mathrm{~min}$, and centrifuged at $13,000 \mathrm{~g}$ for $3 \mathrm{~min}$. The supernatant was carefully transferred into a clean $1.5 \mathrm{ml}$ microcentrifuge tube containing $600 \mu \mathrm{l}$ isopropanol (Merck, Germany) and the mixture was gently mixed by inverting the tube. The mixture was then centrifuged at $13,000 \mathrm{~g}$ for $3 \mathrm{~min}$ and the supernatant was discarded. The pellet was then washed with $600 \mu \mathrm{l}$ of $70 \%$ ethanol (Merck, Germany) by centrifuging at $13,000 \mathrm{~g}$ for 3 min. Finally, the ethanol was discarded and the pellet containing the genomic DNA was re-hydrated by adding $100 \mu \mathrm{l}$ DNA rehydration solution.

\section{DNA extraction from standard bacteria and samples' enriched media}

The total genomic DNAs from all standard bacteria strains (Table 1) and samples' enriched bacteria were extracted using the same Wizard $^{\circledR}$ Genomic DNA purification kit (Promega Corporation, Madison, USA) used for the DNA extraction of samples.

\section{Quality and yield of extracted nucleic acids}

Different DNA extraction methods were evaluated on the basis of performance in agarose gel electrophoresis. Gel electrophoresis of extracted genomic DNA was conducted together with a ready-to-use VC $1 \mathrm{kbp}$ Plus DNA Ladder as a molecular weight standard (Vivantis, Italy). The extracted DNA was also checked by using UVVisible spectrophotometer (UV-1601 Shimadzu Model, Japan) at $260 \mathrm{~nm}$ and $280 \mathrm{~nm}$. The quality of DNA was determined by $A_{260} / A_{280}$ ratio value. DNA yield, in terms of DNA concentration, was being calculated. The formula for the calculation of DNA yield was as follows:

DNA concentration $(\mu \mathrm{g} \mu \mathrm{l}-1)=(\mathrm{A} 260$ in OD units $\times 50$ $\mu \mathrm{gml}-1$ x DF) / 1000.

DNA yield $(\mu \mathrm{g})=$ DNA concentration $(\mu \mathrm{g} \mu \mathrm{l}-1) \times$ amount of DNA kept as stock $(100 \mu \mathrm{l})$.

The total genomic DNA was stored at $0-5^{\circ} \mathrm{C}$ for further 
Table 1. Standard bacterial strains used in this study.

\begin{tabular}{|l|l|}
\hline \multicolumn{1}{|c|}{ Bacterial strains } & \multicolumn{1}{|c|}{ Sources } \\
\hline B. pseudocatenulatum G4 & Morinaga Milk Industry, Japan \\
B. pseudocatenulatum F81 & \\
B. longum BB536 & \\
\hline B. longum JCM 1260 & Isolated from Yakult B1 Seichoyaku Product, Japan \\
B. longum JCM 1210 & \\
B. longum JCM 1217 & \\
B. breve ATCC 15700 & \\
B. breve strain Yakult & \\
\hline B. infantis ATCC 15697 & \\
B. animalis ATCC 27672 & \\
L. brevis ATCC 14869 & \\
L. gallinarium ATCC 33199 & Isolated from Yakult ${ }^{\circledR}$ Drink, Japan \\
L. reuteri ATCC 23272 & \\
L. casei strain Shirota & \\
\hline Lactobacillus acidophilus & \\
\hline L. rhamnosus GG ATCC 53103 & \\
E. faecalis JCM 5803 & \\
E. faecalis S 256 & \\
S. choleraesuis JCM 6977 & \\
S. choleraesuis ATCC 14028 & Research, Kuala Lumpur, Malaysia \\
S. enteritidis (Group D) ATCC 13076 & \\
S. typhimurium S917 & \\
B. ovatus ATCC 8483 & \\
B. uniformis ATCC 8492 & \\
B. vulgates ATCC 8482 & \\
B. thetaiotaomicron ATCC 29741 & Ledical \\
E. coli JM 109 & \\
E. coli K-12 & \\
E. coli E1 & \\
\hline
\end{tabular}

analysis. The best yield and quality of the extracted DNA determined which method would then be used to continue for PCR assays.

\section{Standard bacterial strains and growth conditions}

The standard bacterial strains used in this study were composed of six different genera covering 29 strains. Two LAB genera cover six strains of Lactobacillus and two strains of Enterococcus fecalis and four non-LAB genera cover ten strains of Bifidobacterium, four strains of Salmonella, four strains of Bacteroides and three strains of E. coli (Table 1). The strains of probiotic bacteria, Lactobacillus and Bifidobacterium were grown anaerobically in MRS and TPY broths, respectively. On the other hand, the strains of Salmonella, Enterococcus fecalis and $E$. coli were grown in aerobic condition in nutrient media while Bacteroides spp. were grown in anaerobic condition in nutrient media. All bacteria were incubated for $24-72 \mathrm{~h}$ at $37^{\circ} \mathrm{C}$.

\section{Primers}

Two different genus-specific primer sets were used in this study, (g-Bifid-F/g-Bifid-R) for Bifidobacterium and (Lacto16S-F / Lacto-16S-R) for Lactobacillus (Table 2). These primers were used to detect and quantify the speciesspecific highly conservative region of 16S rRNA gene. gBifid-F/g-Bifid-R primer set (Promega, USA) was customized according to a previous study (Matsuki et al., 2004). On the other hand, Lacto-16S-F/Lacto-16S-R primer set was designed and customized from the nucleotide sequence of Lactobacillus brevis ATCC 14869 (accession no. EU194349) using Primer-BLAST program (NCBI, GenBank, BLAST). The primer set was synthesized in the First Base Laboratories, Shah Alam, 
Table 2. Primer sets used in this study.

\begin{tabular}{|l|l|l|l|l|l|}
\hline $\begin{array}{c}\text { Target } \\
\text { organism }\end{array}$ & \multicolumn{1}{|c|}{ Primer Set } & \multicolumn{1}{|c|}{ Sequence (5' to 3') } & $\begin{array}{c}\text { Product Size } \\
(\mathbf{b p})\end{array}$ & $\begin{array}{c}\mathbf{T}_{\mathrm{a}}\left({ }^{\circ} \mathbf{C}\right), \\
\text { time }(\mathbf{s})\end{array}$ & \multicolumn{1}{c|}{ Reference } \\
\hline $\begin{array}{l}\text { Lactobacillus } \\
\text { genus }\end{array}$ & $\begin{array}{l}\text { Lacto-16S-F } \\
\text { Lacto-16S-R }\end{array}$ & $\begin{array}{l}\text { GGA ATC TTC CAC AAT GGA CG } \\
\text { CGC TTT ACG CCC AAT AAA TCC GG }\end{array}$ & 216 & $56,10 \mathrm{~s}$ & $\begin{array}{l}\text { This study } \\
\text { This study }\end{array}$ \\
\hline $\begin{array}{l}\text { Bifidobacterium } \\
\text { genus }\end{array}$ & $\begin{array}{l}\text { g-Bifid-F } \\
\text { g-Bifid-R }\end{array}$ & $\begin{array}{l}\text { CTC CTG GAA ACG GGT GG } \\
\text { GGT GTT CTT CCC GAT ATC TAC A }\end{array}$ & $562(549-563)$ & $61,20 \mathrm{~s}$ & $\begin{array}{l}\text { Matsuki et al. (2004) } \\
\text { Matsuki et al. (2004) }\end{array}$ \\
\hline
\end{tabular}

Malaysia and was named Lacto-16S-F and $-R$. Since the specificity of Lacto-16S-F/Lacto-16S-R was not evaluated before, two levels of specificity checkup was thoroughly undertaken. Firstly, the specificity of Lacto-16S-F/Lacto$16 S-R$ primer set was proven by using Primer-BLAST program (NCBI, GenBank, BLAST). BLAST-Primer program was set to (nr) parameter where All GenBank + RefSeq Nucleotides + EMBL + DDBJ + PDB sequences are included and the database of unintended gene sequences was unlimited to certain organism to increase the range of specificity checking. It was found that Lacto$16 \mathrm{~S}-\mathrm{F}$ and $-\mathrm{R}$ was highly specific to all Lactobacillus species where complete complementarily was found. On the other hand, nucleotide sequences rather than that of Lactobacillus spp. turned to be uncomplimentary. In addition, the specificity of Lacto-16S-F/R primers was checked in laboratory. Eight strains from LAB genera, Lactobacillus and Enterococcus and 21 strains from nonLAB genera, Salmonella, Bifidobacterium, Bacteroides and $E$. coli, (Table 1) were subjected for recognition by Lacto-16S-F / Lacto-16S-R primer set using PCR assay.

\section{PCR reaction}

After determining the most efficient method of DNA extraction, PCR reaction for DNA extracted from samples, samples' enriched bacteria and standard bacteria, in duplicates, was carried out in a total volume of $25 \mu \mathrm{l}$ with a reaction mixture containing $2.5 \mu \mathrm{l}$ of $10 \times$ PCR buffer, $1.5 \mu \mathrm{l}$ of $25 \mathrm{mM} \mathrm{MgCl}_{2}, 0.5 \mu \mathrm{l}$ of $10 \mathrm{mM}$ dNTP, $1.65 \mu \mathrm{l}$ of $15 \mu \mathrm{M}$ forward and reverse primers of $\mathrm{g}$-Bifid-F / g-Bifid- $\mathrm{R}$ and Lacto-16S-F / Lacto-16S-R, $0.125 \mu$ of $5 u^{-1} l^{-1}$ Taq DNA polymerase, $3 \mu \mathrm{l}$ of genomic DNA $(\sim 10 \mathrm{ng})$ and $14.075 \mu \mathrm{l}$ of sterile distilled water. All the reaction mixtures were obtained from Promega Corporation, Madison, USA.

The reaction mixture in micro-centrifuge tube was amplified in a thermocycler PCR system (PTC-110 ${ }^{\mathrm{TM}}$ Model, MJ Research, Inc., USA). For Bifidobacterium spp., the initial denaturation was performed at $95^{\circ} \mathrm{C}$ for 3 min and the target DNA was amplified in 40 cycles. Each cycle consisted of denaturation $\left(95^{\circ} \mathrm{C}, 30 \mathrm{~s}\right)$, annealing $\left(57^{\circ} \mathrm{C}, 30 \mathrm{~s}\right)$ and extension $\left(73^{\circ} \mathrm{C}, 60 \mathrm{~s}\right)$. The final extension step was performed at $73^{\circ} \mathrm{C}$ for $5 \mathrm{~min}$ and the holding temperature was $10^{\circ} \mathrm{C}$. For Lactobacillus spp., the same PCR cycle and conditions were pursued except for the annealing temperature which was performed at $61^{\circ} \mathrm{C}$ for $30 \mathrm{~s}$. It is noteworthy to mention that negative control, master mix devoid of genomic DNA and positive control, a positive sample taken from previous experiments, were used simultaneously in duplicates.

\section{Gel electrophoresis}

The amplified PCR products were checked for the expected size on $1.5 \%(\mathrm{w} / \mathrm{v})$ agarose gel (LE analytical grade, Promega, Madison, USA). Ten $\mu$ l of each PCR amplified product and $3 \mu \mathrm{l}$ of $6 \times$ Loading Dye were loaded into agarose gel and run in $1 \times$ TBE buffer $(0.089$ M Tris-HCl, $0.089 \mathrm{M}$ Boric acid, $0.002 \mathrm{M}$ EDTA, pH 8.3) (Promega, USA). A ready-to-use VC 100 bp Plus DNA Ladder - molecular weight standard (Vivantis, Italy) was used along with positive control, negative control and PCR amplified products. The PCR products were separated by an electrophoresis system at a constant voltage of $80 \mathrm{~V}$ for $50 \mathrm{~min}$. Then, the gel was stained in ethidium bromide (Sigma, USA) staining $\left(0.5 \mathrm{\mu gml}^{-1}\right)$ for 5 min and followed by washing with distilled water for about 30 min. Finally, the gel was visualized under UV transilluminator (Vilber Lourmat, Cedex, France) and the photos were taken using gel documentation system (Bio Rad Gel Doc 2000 Model Imaging System).

\section{Standard curve for real-time PCR}

In order to quantify Lactobacillus and Bifidobacterium spp. in the tested samples, serially diluted DNA of standard Lactobacillus brevis ATCC 14869 and the standard Bifidobacterium longum strain JCM 1260 were used to generate a standard curve for the mathematical conversion of $\mathrm{Ct}$ values into bacterial cell number. Ct value is the cycle number where the reaction fluorescence exceeds background fluorescence. Two different standard curves for Bifidobacterium spp. and Lactobacillus spp. were generated. Stock plasmid DNA was prepared for these two different bacteria. For the preparation of plasmid DNA, the purified PCR product of interest was prepared first. Ligation of PCR product of interest into pGEM ${ }^{\circledR}$-T Easy Vector (Promega, Madison, USA) which 
consisted of a mixture of $2 \times$ rapid ligation buffer, pGEMTR Easy Vector, purified PCR product, T4 DNA ligase and sterile distilled water. E. coli competent cells of strain JM 109 were used to carry pGEM $^{\circledR}$-T Easy Vector (Promega, Madison, USA) that had been ligated with the target sequence from each bacterial genus. The screening of plasmid insert was done, where the white colony indicated that the PCR product gene of interest was successfully cloned and transformed. The white colony was inoculated into Luria broth supplemented with ampicillin. The plasmid DNA of interest was then extracted from the cell according to the manufacturer's instruction using Wizard ${ }^{\circledR}$ Plus SV Minipreps (Promega, Madison, USA). The initial concentration of the plasmid DNA of interest was $10.6 \mathrm{ug} / \mathrm{ml}$. The plasmid with the correct insert was then 10 -folds serially diluted into six dilutions. Since the molecular weight of the plasmid DNA is known, the concentration of these dilutions were then transformed into the log copy number which was plotted against the threshold cycle $(\mathrm{Ct})$ to generate the standard curve used for the absolute quantification of real-time PCR.

\section{Quantitative real-time PCR}

After the conventional PCR, the genomic DNA obtained either directly from the tested samples or from standard bacterial strains was used for the real-time PCR amplification. Genomic DNA of standard Bifidobacterium and Lactobacillus strains were included in the real-time PCR assay as a positive control while PCR mixture solution devoid of genomic DNA was used as negative control. Real-time PCR amplification reaction was performed with Rotor-Gene ${ }^{\mathrm{TM}} 3000$ (Corbett. Research, Australia) using fluorescent dye SYBR Green (Qiagen ${ }^{T M}$ QuantiTect ${ }^{\circledR}$ SYBR Green PCR kit). The reaction was performed in a total volume of $25 \mu \mathrm{l}(2.5 \mu \mathrm{l}$ of $10 \times \mathrm{PCR}$ buffer), with the composition of the reaction mix per sample as follows: $1.8 \mu \mathrm{l}$ of $25 \mathrm{mM} \mathrm{MgCl}, 0.75 \mu \mathrm{l}$ of 10 mM dNTP, $9.5 \mu \mathrm{l}$ SYBR Green, $1.0 \mu \mathrm{l}$ of $25 \mu \mathrm{M}$ each reverse and forward primers ( $\mathrm{g}$-Bifid- $\mathrm{F} / \mathrm{g}$-Bifid-R and Lacto-16S-F / Lacto-16S-R), $0.125 \mu \mathrm{l}$ of $5 \mathrm{uul}^{-1}$ Taq DNA polymerase, $5.0 \mu \mathrm{l}$ DNA template $(\sim 16 \mathrm{ng})$ and $5.82 \mu \mathrm{l}$ RNase free water. All the reaction mixtures were obtained from Promega Corporation, Madison, USA. The serially diluted bacterial standard and samples were simultaneously assayed in real-time amplification.

The PCR program consisted of an initial denaturation step, amplification step (40 cycles) and a melting-curve determination step. The condition for the amplification was as same as the conventional PCR. Following amplification, melting temperature analysis of PCR products was performed to determine the specificity of the PCR. The melting curves were obtained by slow heating at $0.2^{\circ} \mathrm{Cs}^{-1}$ increments from $60-99^{\circ} \mathrm{C}$, with continuous fluorescence collection. Analysis of PCR amplification and melting curves were done by RotorGene Real-Time Data Acquisition and Analysis Software version 1.7 (Corbett Research, Australia). Measurement of the SYBR Green fluorescence was performed at the end of each amplification step and continuously during the melt-curve analysis (Masco et al., 2007). A melting curve would be generated at the end of amplification for monitoring specificity of PCR reaction.

\section{RESULTS}

\section{Quality and yield of extracted DNA}

The purity and quality of DNA extracted from complex microbial samples are important for proper PCR-based detection assays. Thus, in the experimental design, $A_{260} / A_{280}$ ratio of extracted DNA from tested samples was evaluated. The quality of the extracted DNA was determined by agarose gel electrophoresis too, where the sharpness of the DNA band was visualized. Besides quality, the extracted DNA yield was also important for a subsequent analysis of PCR. Table 3 showed the results of the quality and yield of the extracted DNA using four different extraction methods. Results for DNA quality showed that all DNAs extracted from fish sauce and shrimp sauce using phenol-chloroform method, boiling method and kimchi method gave an $\mathrm{A}_{260} / \mathrm{A}_{280}$ ratio less than 1.5. However, all the DNAs extracted from fish sauce and shrimp sauce using Wizard protocol had an $\mathrm{A}_{260} / \mathrm{A}_{280}$ ratio of more than 1.5 which showed that the quality of DNA produced by Wizard protocol was the best among the four methods.

A good DNA extraction method should not give only high DNA purity, but also high DNA yield. The results in Table 3 showed that the DNA extracted with Wizard protocol produced the highest yield compared to the other three methods. The trend was almost similar to the $\mathrm{A}_{260} / \mathrm{A}_{280}$ ratio of DNA quality. The DNAs extracted using four methods were observed for degradation by agarose gel electrophoresis. It was observed that all DNAs extracted from fish sauce and shrimp sauce by Wizard protocol produced bands at the uppermost part of the gel. For the other three methods, the results of agarose gel electrophoresis revealed that some of the bands were not detected which showed that not all DNAs were liberated during the DNA extraction from each fish sauce and shrimp sauce (Figure 1).

\section{Primer specificity}

The specificity of the used primer set, Lacto-16S-F/Lacto16S-R, was tested before conducting PCR and real-time PCR assays on the complex microbial samples to ensure 
Table 3. Quality and yield of the extracted DNAs using four different protocols.

\begin{tabular}{|l|c|c|c|c|}
\hline \multicolumn{1}{|c|}{ Sample } & $\begin{array}{c}\text { Phenol-chloroform } \\
\text { extraction }\end{array}$ & $\begin{array}{c}\text { Boiling } \\
\text { method }\end{array}$ & $\begin{array}{c}\text { Wizard } \\
\text { protocol }\end{array}$ & $\begin{array}{c}\text { Kimchi } \\
\text { method }\end{array}$ \\
\hline \multicolumn{5}{|c|}{ DNA quality $\left(\mathbf{A}_{\mathbf{2 6 0}} / \mathbf{A}_{\mathbf{2 8 0}}\right)$} \\
\hline Fish sauce A & 1.1083 & 1.1875 & 1.6549 & 1.012 \\
Fish sauce B & 1.0135 & 1.1683 & 1.5828 & 1.0132 \\
Fish sauce C & 1.1613 & 1.0348 & 1.5175 & 1.0500 \\
Shrimp sauce D & 1.0230 & 1.0825 & 1.6783 & 1.0238 \\
Shrimp sauce E & 1.0390 & 1.1375 & 1.5620 & 1.1467 \\
Shrimp sauce F & 1.0762 & 1.1735 & 1.5840 & 1.0465 \\
\hline \multicolumn{5}{|c|}{ DNA yield $(\boldsymbol{\mu g})$} \\
\hline Fish sauce A & 66.5 & 93.5 & 42.0 \\
Fish sauce B & 66.5 & 59.0 & 119.5 & 38.5 \\
Fish sauce C & 37.5 & 59.5 & 108.5 & 42.0 \\
Shrimp sauce D & 46.5 & 52.5 & 120.0 & 43.0 \\
Shrimp sauce E & 44.5 & 45.5 & 94.5 & 43.0 \\
Shrimp sauce F & 40.0 & 49.0 & 99.0 & 45.0 \\
\hline
\end{tabular}
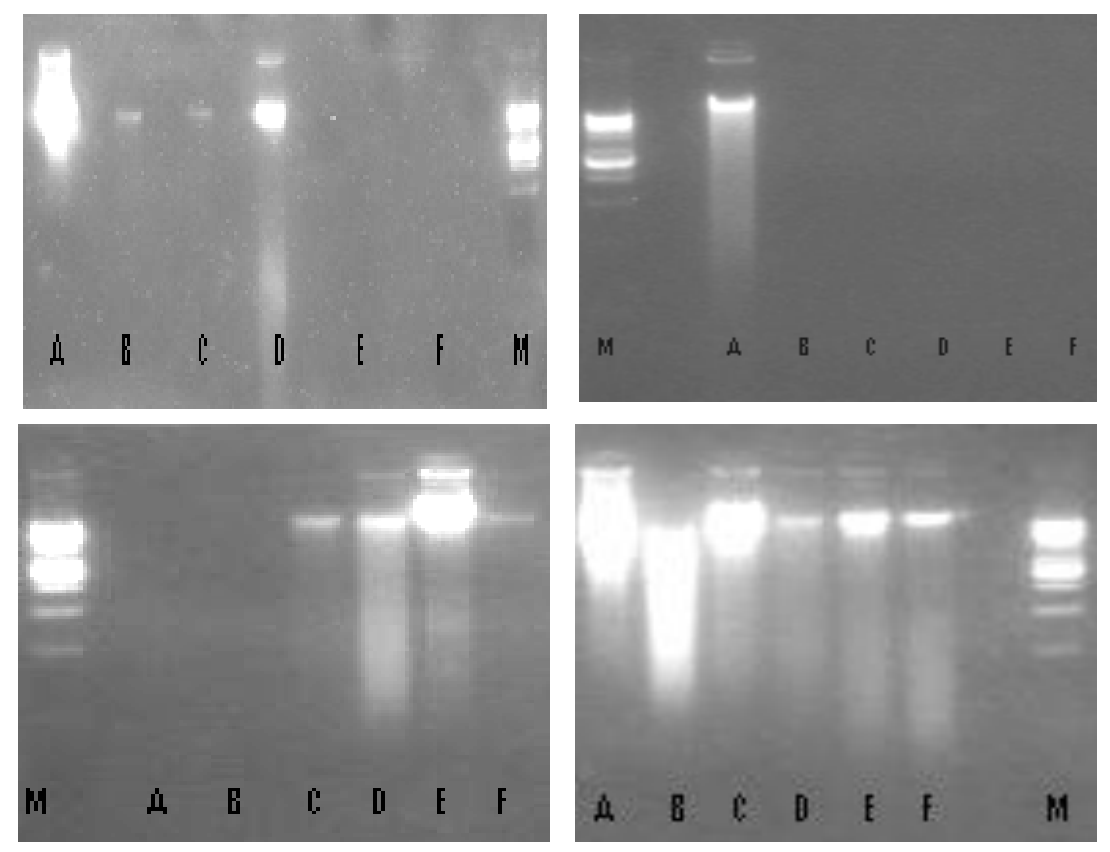

Figure 1. Agarose gel electrophoresis of genomic DNA extracted from fish sauce and shrimp sauce samples with four different methods. Upper left $=$ Phenolchloroform method; Upper right $=$ Kimchi method; Lower left $=$ Boiling method; Lower right $=$ Wizard protocol. Lane $\mathrm{M}=1 \mathrm{~Kb}$ DNA ladder Marker; Lane $\mathrm{A}-\mathrm{C}=$ Fish sauce $A, B$, and $C$; Lane D - F = Shrimp sauce D, E and F.

a proper and specific amplification process. The The specificity of the PCR primer set Lacto-16S-F/Lacto-16S$\mathrm{R}$ was tested by PCR assay with strains other than Lactobacillus spp. and most commonly found in complex microbial samples, including Bifidobacterium spp., Enterococcus spp., Salmonella, E. coli, and bacteroides. All used strains of Lactobacillus were PCR positive to the
Lactobacillus genus specific primer set Lacto-16SF/Lacto-16S-R while all other bacteria proved to be negative. Therefore, in conjunction with specificity check via Primer-BLAST program, the specificity of Lacto-16SF/Lacto-16S-R has been proven for the 16S rRNA gene fragment which is a strain-specific DNA for almost all Lactobacillus spp. 


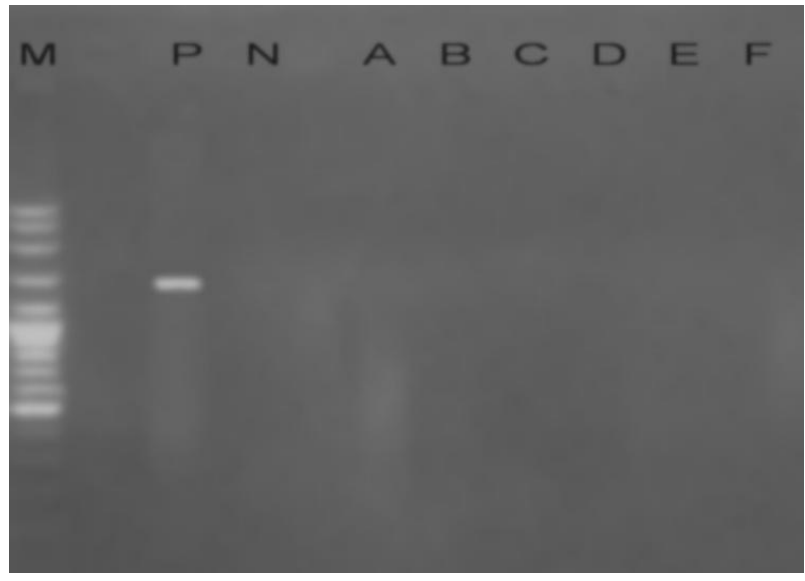

Figure 2. Agarose gel electrophoresis of PCR product amplified from Bifidobacterium spp. in fish sauce and shrimp sauce samples. Lane $\mathrm{M}=100 \mathrm{bp}$ DNA ladder Marker; Lanes $\mathrm{P}$ and $\mathrm{N}$ are positive and negative controls respectively; Lane $A-C=$ fish sauce $A, B$ and $C$; Lane $D$ $F=$ shrimp sauce $D, E$ and $F$. No positive PCR band at 562 was seen at any of tested samples.

\section{PCR detection of Bifidobacterium spp. and Lactobacillus spp.}

The molecular identification of target Bifidobacterium spp bacteria using DNA extracted directly from tested samples for PCR indicated that, even though specific band with molecular weight of 562 bp was found at the lane of the positive control, there was no specific bands with molecular weight of 562 bp observed in all the six tested samples (Figure 2). This indicated that, in the preliminary testing, Bifidobacterium spp. was absent in all of the samples. On the contrary, DNA of Lactobacillus spp. extracted directly from tested samples was detected in one of the three fish sauce samples and in all three shrimp samples (Figure 3 ) by observing a specific band, PCR product with molecular weight of $216 \mathrm{bp}$. However, the band for shrimp sauce D was hardly seen (Figure 3 ). On the other hand, DNA extracted from samples' enriched bacteria in MRS and TYP media revealed that Lactobacillus spp., unlike DNA extracted directly from samples, was detected in all 6 samples including fish sauce $A$ and $B$ while for Bifidobacterium spp the same findings were found that all samples were negative [data not shown].

\section{Real-time PCR Quantification of Bifidobacterium spp. and Lactobacillus spp.}

By incorporating the standard curve for the absolute quantification of bacteria in terms of Log CFU ml ${ }^{-1}$ via inversely proportioning the amount of the positively amplified bacteria to $\mathrm{Ct}$ value, it was shown that all

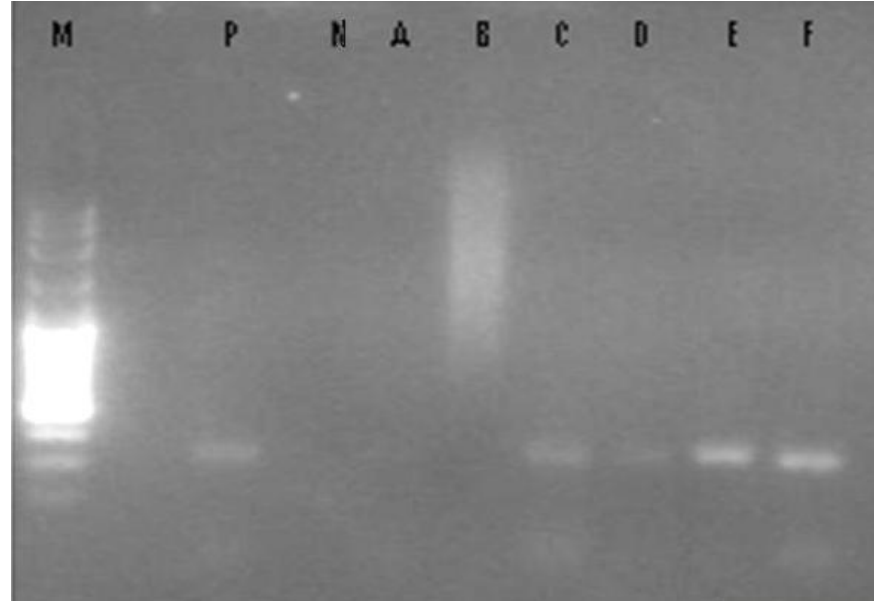

Figure 3. Agarose gel electrophoresis of PCR product amplified from Lactobacillus spp. in fish sauce and shrimp sauce samples. Lane $M=100 \mathrm{bp}$ DNA ladder Marker Lanes $\mathrm{P}$ and $\mathrm{N}$ are positive and negative controls respectively; Lane $A-C=$ fish sauce $A, B$ and $C$; Lane $D-F=$ shrimp sauce $D, E$ and $F$. Positive PCR bands at $216 \mathrm{bp}$ were only found in C, D-F samples.

samples of fish and shrimp sauce yielded positive Lactobacillus. Moreover it was shown that fish sauce A had the lowest amount of Lactobacillus spp., while shrimp sauce $F$ had the highest amount of Lactobacillus spp (Table 4). On the contrary, real-time PCR for Bifidobacteria did not reveal any sign of amplification indicating the possibility of the absence of this bacteria or inability of its detection. For DNA extracted from samples' enriched bacteria, the findings were similar; the detection of Bifidobacterium spp. was again negative and the detection of Lactobacillus spp. was positive in all samples but with bacterial load 3 to 4 Log CFU ml ${ }^{-1}$ higher than that detected directly from the tested samples.

On the other hand, by using the melting curve analysis during the real-time PCR reaction, it was observed that $T_{m}$ value for the serially diluted standard Bifidobacterium strains was located about $89^{\circ} \mathrm{C}$. The findings showed that there was no specific peak at $\mathrm{T}_{\mathrm{m}}=89^{\circ} \mathrm{C}$ for the DNA extracted directly or via enrichment step from all samples of the fish and shrimp sauce. Therefore, in addition to the conventional PCR and quantitative real-time PCR, melting curve analysis provided extra evidence that Bifidobacterium spp. were most likely absent in all tested samples.

On the other hand, the $T_{m}$ value for the serially diluted standard Lactobacillus strains was located about $85.5^{\circ} \mathrm{C}$. It was shown, for DNAs extracted directly from samples or via bacterial enrichment, that the melting curve for Lactobacillus spp. in three fish sauce (A, B and C) and three shrimp sauce (D, E and $F$ ) had a specific peak at $\mathrm{T}_{\mathrm{m}}=85.5^{\circ} \mathrm{C}$ for each of the six samples, pointing out that all the tested samples contained Lactobacillus spp. Therefore, the Lactobacillus spp. sharp peak in the 
Table 4. Comparison of Ct value and Lactobacillus spp. in fish sauce and shrimp sauce by Real- Time PCR.

\begin{tabular}{|l|c|c|}
\hline Sample & Ct value & $\begin{array}{c}\text { Real-Time PCR } \\
\text { (Log CFUml }^{-1} \text { ) }\end{array}$ \\
\hline Fish sauce A & 24.44 & 5.53 \\
Fish sauce B & 24.17 & 5.67 \\
Fish sauce C & 22.67 & 6.41 \\
Shrimp sauce D & 23.97 & 5.77 \\
Shrimp sauce E & 22.12 & 6.68 \\
Shrimp sauce F & 22.28 & 6.60 \\
\hline
\end{tabular}

** The efficiency of the standard curve was $\mathrm{R}^{2}=0.99959$.

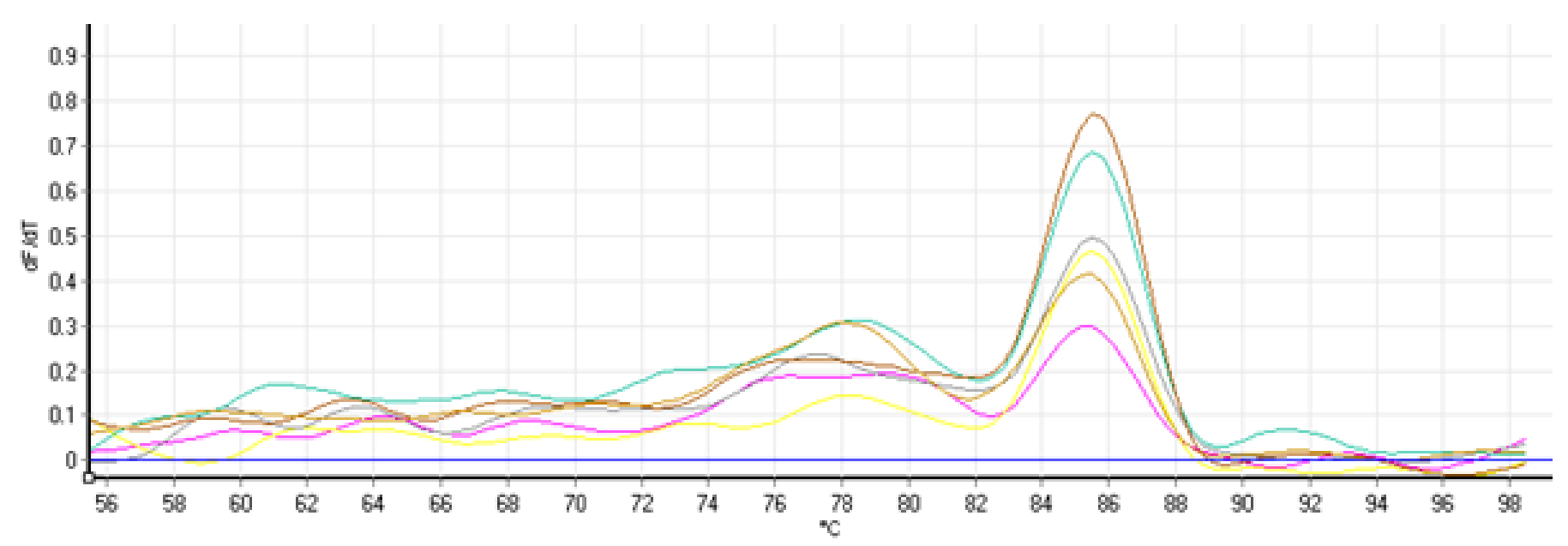

Figure 4. Melting curve analysis of Lactobacillus spp. for three fish sauce and three shrimp sauce samples. The peak $\left(T_{m}=85.5^{\circ} \mathrm{C}\right)$ is specific to the genus Lactobacillus spp. (The peak from top to bottom: shrimp sauce $E$, shrimp sauce $F$, fish sauce $C$, shrimp sauce $D$, fish sauce $B$, fish sauce $A$ ).

melting curve was a further confirmation of the conventional PCR result (Figure 4).

In addition, it was important to confirm that there were no products of non-specific amplification, including primer dimers that contributed to the signal. This was detected by using the melting curve analysis too. In this study, there was just a weak signal appearing at a lower temperature than the $T_{m}$ for both the Bifidobacterium spp. and Lactobacillus spp. in all fish sauce and shrimp sauce samples, which was identified as primer-dimers. The presence of these primer-dimers might be due to the insufficient primer annealing time, or the inappropriate annealing temperature.

\section{DISCUSSION}

The main species believed to have probiotic characteristics are Lactobacillus spp. and Bifidobacterium spp. This study attempted to work out two problems facing the microbial analysis of probiotics from complex microbial samples. First, the reliability of many enumeration procedures of probiotic bacteria is compromised by the lack of suitable media for the selective isolation of these organisms from probiotic products. Secondly, the microbial analysis of some bacteria in fermented products mostly was done using culture-dependent methods which were imprecise and time-consuming (Martin et al., 2006). Therefore DNA amplification methods, PCR, are more intended and used for their invaluable preciseness. However, PCR assays need a lot of optimization and standardization prior to any valid testing especially for detecting microflora in highly mixed complex environments.

Quality and yield of the extracted DNA are primary requirements for the PCR-based detection assay. The selection of suitable extraction method is essential for a successful and valid PCR analysis. The main limitation associated with PCR application for the detection of microorganisms in complex matrices is the presence of inhibitory substances that are co-extracted with DNA, 
causing failure in the amplification reaction which leads to false negative results. In fermented fish products which contain a high number of inhibitory substances such as proteins, a suitable DNA extraction method seems to be very important (Podar et al., 2007). Thus, prior to PCR amplification, the quality and yield of the extracted genomic DNA had to be determined.

The purity of DNA was indicated by $A_{260} / A_{280}$ ratio, where the value from 1.8 to 2.0 was considered as high purity. Nevertheless, the extracted DNA is considered of adequate purity if $A_{260} / A_{280}$ is $>1.5$ (DNA Quantification: Spectrophotometry, 10/2004). In this study, only the extracted DNA by Wizard protocol had a quality more than 1.5. This might be due to the additional step of protein precipitation in the protocol. Martin et al. (2006) stated that DNA isolation done by Wizard protocol from fermented sausage and meat allowed an increase in the amount of the purified DNA sample added to the realtime PCR without inhibitory consequences.

Regarding DNA integrity, the detection of bacteria using PCR method is dependent on the ability to extract intact DNA from food samples. If an appropriate method was used, the efficiency to recover DNA could be maximized even for complex and highly processed matrices (Tung et al., 2008). Although fish sauce and shrimp sauce are fermented products which might affect DNA integrity, the high molecular weight single band obtained for all of the four methods at the uppermost gel indicated that DNA was not fragmented. Although the extracted DNA by Wizard protocol was not in the highest purity $\left(A_{260} / A_{280}=1.8\right.$ to 2.0$)$, they could be used in the subsequent PCR detection of bacteria in fish sauce and shrimp sauce because of the most intact DNA and the highest DNA yield compared to the other three methods.

Regarding DNA yield, for Wizard protocol, the obtained high yield of DNA was probably attributed to the addition of lysozyme, a required pre-processing step to efficiently breakdown peptidoglycan in the cell wall of gram-positive bacteria. A previous study showed that the yield of extracted DNA was high when cell pellet was lysed with lysozyme (Pitcher et al., 1989). For Kimchi method and phenol-chloroform method, the low DNA yield was probably due to the quality of enzyme used for the lysis of cell, which was the proteinase $\mathrm{K}$. Treatment with proteinase $\mathrm{K}$ was very dependent on the quality of the enzyme where lysis of cells can be affected at long term storage of proteinase K (Agersborg et al., 1997). For boiling method, the low DNA yield was probably due to the heatresistance of some fastidious strains found in fermented samples.

Although Wizard protocol produced relatively high yield of DNA compared to other three methods, the extracted DNA was not in optimum. According to Velazquez et al. (1993), the readjustment of $\mathrm{pH}$ of lysis mixture to 8.0 after addition of lysozyme proved to be definitive in subsequent cell lysis of gram-positive bacteria. Omission of this step caused incomplete lysis of cell and subsequent low yield DNA being extracted. Thus, in this study, DNA extraction using Wizard protocol could be improved to maximize the yield of DNA obtained.

The other requirement for well optimized PCR is the specificity of the used primers. It is well known that primer specificity of any target bacteria in complex microbial community is very important prior to the use of PCRbased assay. Therefore, since the specificity of Bifidobacterium primer set, g-Bifid-F/g-Bifid-R, had been tested in a study done by Matsuki et al. (2004), the specific primer set of Lactobacillus spp., Lacto-16SF/Lacto-16S-R, was subjected to a thorough testing via both Primer-BLAST program and laboratory testing. It was found that Lacto-16S-F/Lacto-16S-R was highly specific for Lactobacillus $\mathrm{sp}$ rather than other known bacteria listed in Genbank database. In addition, to keep the optimal fidelity, a thorough search in BLAST program for any complimentary sequence in species other than bacteria which showed totally negative results. Moreover, this primer was specific for Lactobacillus spp. rather than other laboratory-tested bacteria, namely, Bacteroides, Enterococcus, E. coli and Salmonella. This grants validity for using this primer in the subsequent PCR-based assays and abolish the main obstacle of using PCR in complex microbial communities, which is the possibility of cross reaction and non-specificity.

After standardizing PCR adequately, which is the first aim of this study, the findings of detecting Lactobacillus spp. and Bifidobacterium spp. can be discussed in confidence. In conventional PCR, the absence of Lactobacillus spp. in fish sauce A and B might be due to the variation in chemical composition and quality characteristic of the fermented fish products. This could be related to the method of processing and the raw material used. Some of the strains of Lactobacillus were unable to grow in such a low $\mathrm{pH}$ condition of fermented fish products. According to Itoh et al. (1985), some of the fish sauces from Thailand which contained levulinic acid had low microfloral viable counts, because levulinic acid suppressed the growth of bacteria. However, there was possibility that some of the DNAs were lost during DNA extraction using Wizard protocol. The number of Lactobacillus spp. might be under the detection limit of this PCR condition, and thus the band was hardly to be seen. There was also a possibility that amplification was inhibited by the PCR inhibitor such as high protein or fat content found in fish sauce and shrimp sauce. However, fish sauce $C$, shrimp sauce $A, B$ and $C$ were found to contain Lactobacillus spp., which is tolerable to the high salt condition in fermented fish products which was believed to take part in the fermentation process. A study done by ljong and Ohta (1995) on Indonesian fermented fish sauce "bakasang", among six genera of bacteria identified, Staphylococcus spp. and Lactobacillus spp. were the predominantly isolated microorganisms. 
Regarding real-time PCR of DNA extracted from samples, it turned out to be more sensitive results than that of conventional PCR. Unlike conventional PCR, it succeeded to detect and quantify Lactobacillus spp., in all tested samples. However, for Bifidobacterium spp., like conventional PCR, real time PCR turned negative results. The result obtained for the number of Lactobacillus spp. in samples was between 4 to 6 log units indicating that Lactobacillus is present abundantly in fish and shrimp sauce. However, the quantification might be a bit inaccurate due to the fact that 16S rRNA gene can be present in multiple copies, possibly resulting in an overestimation of the number of Lactobacillus spp. in samples. Moreover, the formation of non-specific amplicons when using SYBR Green dye might cause overestimation of the number of Lactobacillus spp. In fact, the results obtained from the real time PCR of the samples' enriched bacteria were not different from that directed towards direct samples extracted DNA [data not shown]. In Lactobacillus spp. It was positive while Bifidobacterium spp. were absent in all samples' enriched bacteria. Nevertheless, the only difference was the enumeration of Lactobacillus as it was $3-4 \log$ units higher than that obtained from DNA extracted directly from samples. This difference is expected as enrichment step amplified greatly the number of targeted bacteria.

The melting curve analysis was performed immediately after amplification by briefly denaturing PCR products followed by cooling to $5-10^{\circ} \mathrm{C}$ below the $\mathrm{Tm}$ of the detection probe given that $\mathrm{Tm}$ is a function of GC content (Lee et al., 2004; Edwards, 2004). Melting curves were useful for differentiating primer dimers from specific PCR products and to validate the identity of the amplified products where every PCR product has its own melting temperature. Hence, melting curve analysis confirmed the specific amplification for Lactobacillus spp., the absence of Bifidobacterium spp., and the very low level of primer dimers in DNA extracted from both direct samples and samples' enriched bacteria.

Accordingly, no Bifidobacterium sp. was found for all the six samples of fish and shrimp sauce via conventional PCR, quantitative real time PCR, melting curve analysis in both direct samples and samples' enriched bacteria. This might largely exclude the possibility that the negative results of Bifidobacterium spp., were due to either PCR inhibition or very low level of that bacteria because the samples' enriched bacteria did not reveal as well any sign for the presence of Bifidobacterium sp. Until now, no study has been done to detect the presence of this bacterium in fermented fish products and this was the first study to be conducted. There is a minor possibility that the absence of Bifidobacterium spp. might be due to the loss of DNA during the DNA extraction but this contradicts the successful DNA extraction done for Lactobacillus $\mathrm{sp}$. which was present in the same samples. According to Cheng et al. (2008), the sensitivity for PCR detection limit of Bifidobacterium adolescentis in human stool using primers of bits- $1 /$ bits- 2 was until $10^{\circ} \mathrm{CFU} / \mathrm{g}$, while for yogurt sample was until $10^{2} \mathrm{CFU} / \mathrm{ml}$. Bifidobacterium spp. was normally important in milk fermentation, and they are found in human milk as well. Their absence in fish sauce and shrimp sauce for this study might be possible because the condition of the fish sauce and shrimp sauce was suspected not to be suitable for Bifidobacterium spp. that needs a medium rich of all essential nutrients, for example, nitrogen sources. According to Gomes and Malcata (1999), Bifidobacteria tend to exhibit weak growth even in milk, and they need invariably long fermentation times and conditions of anaerobiosis. And it was shown that Bifidobacteria survival depends critically, more than other bacteria, on $\mathrm{pH}$, the presence of competing microorganisms, the storage temperature, and the presence of microbial inhibitors (e.g. $\mathrm{NaCl}$ ) in the food matrix (Kurmann and Rasic, 1991).

Taken together, in this study, culture-independent methods, traditional and real-time PCR, were used to investigate the presence of Bifidobacterium and Lactobacillus in complex microbial communities, fermented fish sauce and shrimp sauce. Among four of the DNA extraction methods being evaluated, Wizard ${ }^{\circledR}$ Genomic DNA Purification Kit was found to be the most efficient DNA extraction method for this study, in terms of DNA purity and yield. Detection by using traditional and realtime PCR proved to be highly efficient for the detection and quantification of Lactobacillus but not Bifidobacterium, most likely due to its absence, in highly crude and PCRsuppressor- contaminated samples. Quantitative real time PCR was shown to be more sensitive than traditional PCR for the detection of probiotic bacteria. Moreover, besides the inaccurate enumeration, the enrichment step for samples' bacteria did not yield better sensitivity for the detection of probiotic bacteria. Accordingly, quantitative real time PCR is highly recommended for the detection and enumeration of Lactobacillus spp., in highly complex microbial communities directly without conducting enrichment of samples' bacteria to save time, effort and cost when compared to culture- or PCR enrichmentbased methods.

\section{ACKNOWLEDGMENT}

This study was funded by University Putra Malaysia along with full scientific support and care.

\section{REFERENCES}

Agersborg A, Dahl R, Martinez I (1997). Sample preparation and DNA extraction procedures for polymerase chain reaction identification of Listeria monocytogenes in seafoods. Int. J. Food Microbiol. 35: 275280

An HR, Mainelis G, White L (2006). Development and calibration of real-time PCR for quantification of airborne microorganisms in air samples. Atmos. Env. 40: 7924-7939. 
Cheng CT, Chieh HL, Yu BI, Hau YT (2008). Use of specific primers based on the $16 \mathrm{~S}-23 \mathrm{~S}$ internal transcribed spacer (ITS) region for the screening Bifidobacterium adolescentis in yogurt products and human stool samples. Food Microbiol. 14: 4, 219-223

Edwards KJ (2004). Performing real-time PCR. In: Edwards K, Logan J, Saunders N (eds) Real-Time PCR, an Essential Guide: Horizon Bioscience. UK, pp. 71-83.

Fairchild A, Lee MD, Maurer JJ (2006). PCR basics. In: Maurer J (eds) PCR Methods In Foods: Springer Science \& Business Media, Inc. USA. New York, pp. 1-25.

Gomes AMP, Malcata FX (1999). Bifidobacterium spp. and Lactobacilus acidophilus: biological, biochemical, technological and therapeutical properties relevant for use as probiotics. Trends Food Sci. Technol. 10: 139-157.

ljong FG, Ohta $Y$ (1995). Microflora and chemical assessment of an Indonesian traditional fermented fish sauce "Bakasang". J. Fac. Appl. Biol. Sci. 34: 95-100

Ishibashi N, Yaeshima T, Hayasawa H (1997). Bifidobacteria: their significance in human intestinal health. Mal. J. Nutr. 3: 149-159.

Isolauri E, Laiho K, Hoppu U, Ouwehand AC, Salminen S (2002). Probiotics: On-going research on atopic individuals. Brit. J. Nut. 88: 19-27.

Itoh H, Hadioetomo RS, Nkkuni S, Okada N (1985). Studies on lactic acid bacteria in fish sauces (part 1): Chemical composition and microflora of fish sauces. Rept. Natl. Food Res. Inst. 47:23-30

Jaspers E, Overmann J (1997). Separation of bacterial cells by isoelectric focusing, a new method for analysis of complex microbial communities. Appl. Environ. Microbiol. 63: 3176-3181.

Keegan H, Boland C, Malkin A, Griffin M, Ryan F, Lambkin H (2005). Comparison of DNA extraction from cervical cells collected in PreservCyt solution for the amplification of Chlamydia trachomatis. Cytopathology. 16: 82-87.

Klein D (2002). Quantification using real-time PCR technology: applications and limitations. Trends Mol. Med. 8: 257-260

Kochl S, Niederstatter H, Parson W (2005). DNA extraction and quantitation of forensic samples using the phenol-chloroform method and real-time PCR. Methods Mol. Biol. 297: 13-30.

Kurmann JA Rasic JL (1991) 'The Health Potential of Products Containing Bifidobacteria' in Therapeutic Properties of Fermented Milks: Elsevier Applied Science Publishers. London. UK, pp. 117-157.

Logan JMJ, Edwards KJ (2004). An overview of real-time PCR platforms. In: Edwards K, Logan J, Saunders N (eds) Real-Time PCR, an Essential Guide: Horizon Bioscience. UK, pp. 13-30.

Lee MA, Squirrell DJ, Leslie DL, Brown T (2004). Homogenous fluorescent chemistries for real-time PCR. In: Edwards K, Logan J, Saunders N (eds) Real-Time PCR, an Essential Guide. Real-Time PCR, an Essential Guide: Horizon Bioscience. UK, pp. 31-70.

Martin B, Jofre A, Garriga M, Pla M, Aymerich T (2006). Rapid quantitative detection of Lactobacillus sakei in meat and fermented sausages by real-time PCR. Appl. Environ. Microbiol. 72: 6040-6048

Masco L, Vanhoutte T, Temmerman R, Swings J, Huys G (2007). Evaluation of real-time PCR targeting the 16S rRNA and recA genes for the enumeration of bifidobacteria in probiotic products. Int. J. Food Microbiol. 113: 351-357
Matsuki T, Watanabe K, Fujimoto J, Kado Y, Takada T, Matsumoto K (2004). Quantitative PCR with 16S rRNA-gene-targeted speciesspecific primers for analysis of human intestinal bifidobacteria. Appl. Environ. Microbiol. 70: 167-173

Muhling M, Woolven-Allen J, Murrell JC, Joint I (2008). Improved groupspecific PCR primers for denaturing gradient gel electrophoresis analysis of the genetic diversity of complex microbial communities. ISME J. 2: 379-392.

Pitcher DG, Saunders NA, Owen RJ (1989). Rapid extraction of bacterial genomic DNA with guanidium thiocyanate. Lett. Appl. Microbiol. 8:151-156.

Podar M, Abulencia CB, Walcher M, Hutchison D, Zengler K, Garcia JA, Holland T, Cotton D, Hauser L, Keller M (2007). Targeted access to the genomes of low-abundance organisms in complex microbial communities. Appl. Environ. Microbiol. 73: 3205-3214.

Ray B, Bhunia A (2008). Fundamnetal Food Microbiology: Taylor \& Francis Group, LLC, CRC Press. USA. pp. 435-457.

Salinas I, Meseguer J, Esteban MA (2008). Antiproliferative effects and apoptosis induction by probiotic cytoplasmic extracts in fish cell lines. Vet. Microbiol. 126: 287-294.

Salminen S, von Wright A, Morelli L, Marteau P, Brassart D, de Vos WM, Fondén R, Saxelin M, Collins K, Mogensen G, Birkeland SE, MattilaSandholm T (1998). Demonstration of safety of probiotics - a review. Int.I J. Food Microbiol. 44:93-106.

Tung NCT, Son R, Raha AR, Lai OM, Clemente WVL (2008). Comparison of DNA extraction efficiencies using various methods for the detection of genetically modified organisms (GMOs). Int. Food Res. J. 16: 123-128.

Umesaki Y, Setoyama H (2000). Structure of the intestinal flora responsible for development of the gut immune system in a rodent model. Micro. Inf. 2:1343-1351.

Velazquez JB, Cansado J, Sieiro C, Calo P, Longo E, Villa TG (1993). Improved lysis of wine lactobacilli for high yield isolation and characterization of chromosomal DNA. J. Microbiol Methods. 17: 247-253.

Yi-Ting K, Yu-Shan L, Yuan-Tay S (2007). Identification of Lactobacillus spp. in probiotic products by real-time PCR and melting curve analysis. Food Res. Int. 40: 71-79.

Yongsawatdigul J, Rodtong S, Raksakulthai N (2007). Acceleration of Thai fish sauce fermentation using proteinases and bacterial starter cultures. J. Food Sci. 72: M382-390. 